\title{
Australian historians and biography
}

\author{
MALCOLM ALLBROOK AND MELANIE NOLAN
}

\section{Australian biography amid the recent biographical turn}

\begin{abstract}
The publication of the first number of the Australian Journal of Biography and History provides an opportunity to reflect on recent Australian biographical practice. ${ }^{1}$ By recent, we mean the last two decades, with our starting point Stuart Macintyre's 1998 survey of biography in the Oxford Companion to Australian History. He noted that the genre was wide-ranging:

The writing of a life is an activity practised by historians in company with other academic, professional and amateur writers. It is a popular and deceptively simple genre that spans the filial memoir and the critical study, and ranges from the formal record to the imaginative re-creation that spills into fiction. ${ }^{2}$
\end{abstract}

Macintyre pointed to a fork in Australian biographical practice in the 1950s (common to western historiographies) when, on the one hand, professional historians turned to biography and, on the other, academic historians developed a newly found 'mistrust', finding defects in adequately comprehending a completed life and a tendency to rely on singularity and individual agency in preference to structural causation. ${ }^{3}$ Biography is perhaps only just starting to shake off this history, although to some it remains academic historians' 'unloved stepchild, occasionally but grudgingly let in the door, more often shut outside with the riffraff. ${ }^{4}$ Macintyre, however, found evidence that Australian historians had 'largely dropped any suspicion of the genre of biography' by the end of the twentieth century, not least because they recognised its considerable potential for bringing historical research to

\footnotetext{
1 The authors thank the three reviewers for their careful reading of the manuscript and their constructive suggestions.

2 Stuart Macintyre, 'Biography', in The Oxford Companion to Australian History, ed. Graeme Davison, John Hirst and Stuart Macintyre (Melbourne: Oxford University Press, 1998), 72.

3 Sabina Loriga, 'The Role of the Individual in History: Biographical and Historical Writing in the Nineteenth and Twentieth Century', in Theoretical Discussions of Biography: Approaches from History, Microhistory, and Life Writing, ed. Hans Renders and Binne de Haan (Leiden: Brill, 2014), 75-89.

4 David Nasaw, 'Introduction', The American Historical Review 114, no. 3 (June 2009): 573-78, doi.org/ 10.1086/ahr.114.3.573.
} 
the attention of a public that had long been an avid consumer of biography. ${ }^{5}$ It had been a highly effective methodology in feminist history. As a consequence of such developments, Macintyre believed that historians 'who regard biography as a mere ancillary of their discipline underestimate it ${ }^{6}{ }^{6}$

Most commentators agree that, while biography remained popular outside the academy in the second half of the twentieth century, academic historians preferred structural and social analyses and downplayed the potential of biography. ${ }^{7}$ Barbara Caine in her 2010 general textbook, Biography and History, pointed to a revival in interest among academic historians at the end of the twentieth century in Australia and beyond. ${ }^{8}$ She observed that:

Biography can be seen as the archetypal 'contingent narrative' and the one best able to show the great importance of particular locations and circumstances and the multiple layers of historical change and experience. ${ }^{?}$

Australian historians' enthusiasm for biography can be measured in various ways. If the sheer quantity of publications is any indication, Australian biography is enjoying, in the words of the late historian Jill Roe, a 'golden age'. ${ }^{10}$ Indeed since 2010 it has been a veritable torrent. The National Library of Australia's catalogue recorded 9,202 items under the subject area 'Australian biography', of which 8,664 were books. A breakdown by decade reveals the vast majority of works categorised as 'Australian biography' have been published since 2000. ${ }^{11}$ Australian biographies are prominent among Australia's best-selling lists. Peter FitzSimons's publishers note that he is 'one of Australia's biggest selling non-fiction authors of the last twenty years'. ${ }^{12}$ He has published biographies of iconic Australian figures such as the Antarctic explorer Douglas Mawson (2011), the bushranger Ned Kelly (2013),

5 For a discussion of academic historians turning again to biography, see Melanie Nolan, 'Country and Kin Calling? Keith Hancock, the National Dictionary Collaboration, and the Promotion of Life-Writing in Australia', in Clio's Lives: Biographies and Autobiographies of Historians, ed. Doug Munro and John G. Reid (Canberra: ANU Press, 2017), 247-72.

6 Macintyre, 'Biography', 72.

7 Hans Renders, Binne de Haan and Jonne Harmsma, eds, The Biographical Turn: Lives in History (London: Routledge, 2016).

8 Barbara Caine, Biography and History (London: Palgrave, Macmillan, 2010), vii. See also Prue Chamberlayne, Joanna Bornat and Tom Wengraft, eds, The Turn to Biographical Methods in Social Science: Comparative Issues and Examples (London and New York: Routledge, 2000). For a discussion on its overuse, see Simone Lässig, 'Introduction: Biography in Modern History-Modern Historiography in Biography', in Biography between Structure and Agency: Central European Lives in International Historiography, ed. Volker R. Berghann and Simone Lässig (New York: Berghann Books, 2008), 3.

9 Caine, Biography and History, 2.

10 Jill Roe, 'Biography Today: A Commentary', in 'Biography and Life-Writing', ed. Tanya Evans and Robert Reynolds, special issue, Australian Historical Studies 41, no. 1 (2012): 107-18.

11 Catalogue search, National Library of Australia website, accessed 5 September 2018, catalogue.nla.gov.au/ Search/Home?lookfor=Australian\%20biography\&filter[]=subject-cluster\%3AAustralian\%20AND\%20format $\% 3$ ABook\&type=all\&narrow $=1$.

12 'Peter FitzSimons', Penguin Books Australia, accessed 28 May 2018, www.penguin.com.au/authors/peterfitzsimons. 
the explorers Burke and Wills (2017), the war heroine Nancy Wake (2011), the federal opposition leader Kim Beazley (1998), the aviator Sir Charles Kingsford Smith (2009), the boxer Les Darcy (2007), the cricketer Steve Waugh (2004), the World Cup-winning Wallaby captains, Nick Farr-Jones (1993) and John Eales (2001), and magazine queen Nene King (2002), as well as numerous military histories and an autobiography of his own childhood. His biography of Wake sold over 84,000 copies in 2017; the average academic tome sells less than 1 per cent of that number. ${ }^{13}$ As Ann Curthoys and Ann McGrath have suggested, 'popular historians often explore topics that others have researched and written extensively, and synthesizing in this way bring the story to a larger audience'. ${ }^{14}$ Popular memoirs can also be blockbusters; for instance, singer Jimmy Barnes's Working-Class Boy sold 132,000 copies in the year 2016-17. ${ }^{15}$ While sheer numbers of sales is a blunt instrument to measure impact, the biographical turn can also be measured in specialist publications. A range of history journals devoted special numbers to biography in the first two decades of the twenty-first century. ${ }^{16}$ Australian historians' recent enthusiasm can be gauged too by the special issue of Australian Historical Studies devoted to biography in 2012. ${ }^{17}$ Australian historians, moreover, have recently been developing a range of kinds of 'scholarly infrastructure' in biography, which we survey below.

The Australian Journal of Biography and History is being launched in response to historiographical developments that are evident locally. We expect a range of papers on Australian lives that experiment with porous boundaries, widen the scope and inclusiveness of the genre and vary conventional with traditional subjects. Australian lives are increasingly being considered in the context of larger cultures. We expect papers that consider whether and in what ways the 'biographising' movement has also contributed to a more fundamental 'shifting configurations of concerns, concepts, and methodologies' in Australian practices. ${ }^{18}$ Australian historians are not only investigating the interiority of their subjects, as much as the sources

13 Figures on HarperCollins website, accessed 28 May 2018, www.harpercollins.com/9781743095713/nancywake-biography-revised-edition/.

14 Ann Curthoys and Ann McGrath, How to Write History That People Want to Read (Sydney: UNSW Press, 2009), 5 .

15 'Think Australian 2017', Books+Publishing, 2017, pamphlet, 19, accessed 28 May 2018, www.booksand publishing.com.au/ThinkAustralian/ThinkAustralian2017.pdf.

16 For instance, the American Historical Review had a special number devoted to Biography in June 2009, the Journal of Interdisciplinary History in Winter 2010 and Cercles: Revue Cercles: Revue Pluridisciplinaire du Monde Anglophone in 2015.

17 Tanya Evans and Robert Reynolds were the editors of the Australian Historical Studies special issue on 'Biography and Life-Writing' (April 2012). It mostly consisted of papers presented to 'Faces in the Street: Biography and Life-Writing', which Evans had organised for History Week at the State Library of New South Wales on 6 September 2010.

18 Tom Wengraf, Prue Chamberlayne and Joanna Bornat, 'A Biographical Turn in the Social Sciences? A BritishEuropean View', Cultural Studies, Critical Methodologies 2, no. 2 (2002): 245-69; Simone Laessig, 'Toward a Biographical Turn? Biography in Modern Historiography-Modern Historiography in Biography', Bulletin of the GHI (Washington), no. 35 (Fall 2004): 147-54. 
allow, a point we shall return to, but also to their experience and role by writing autobiographically in a style sometimes characterised as 'egohistoire. ${ }^{19}$ Secondly, a significant group of Australian historians is concerned with striking a balance between personality and context, and with considering the relationship between micro and macro levels of analysis; individuals are increasingly being considered in the context of larger social structures. We argue that Australian practices seem to differ from what is being described as the Dutch or European 'school of interiority' and these developments beg explanation. ${ }^{20}$

\section{Australian scholarly infrastructure in biography}

Part of the explanation for the growth in publications in Australian biographies lies in the building over the last two decades of a research infrastructure in universities and libraries, supported by government grants and philanthropy. There are now prizes to encourage biographical writing, lectures that feature prominent biographers, biography research centres and courses in universities, public conferences and so on. Philanthropic involvement in the humanities has been notable, but until recently there has been limited commitment to biography, and thus government funding has been the principal driver of such research in the academy. Yet there has been a gradual increase in private support. For example, in 2001, the University of Adelaide's Fred Johns Scholarship for Biography, which had been awarded just five times between 1938 and 1956, was rejuvenated and is now awarded annually. ${ }^{21}$ In 2015 Dr John and Dr Heather Seymour also established a summer scholarship for young postgraduate students undertaking biographical research at the National Library of Australia. Similarly, annual lectures in biographical practice feature in the Australian literary calendar, notably the Seymour series that was endowed in 2005, first in conjunction with the short-lived Biography Institute at The Australian National University (ANU), which functioned from 2005 until 2009, and later the National Library of Australia. This has brought a stream of international and local authors to discuss the genre in its immense variety. ${ }^{22}$ Beginning with Brenda Niall, ${ }^{23}$ the series has alternated between Australian and British practitioners, and has been notable for the variety of its offering, dealing with subjects as diverse as biography in the electronic era (Lawrence Goldman, 2006), Australian identity (Jill Roe, 2007), methodology and ethics (Frances Spalding, 2010), intellectual biography

19 Anna Cole, Karen Hughes and Oliver Haag, Ngapartji, Ngapartji: In Turn in Turn, Egohistoire, Europe and Indigenous Australia (Canberra: ANU Press, 2014).

20 Daniel R. Meister, 'The Biographical Turn and the Case for Historical Biography', History Compass 16, no. 1 (January 2018): e12436, doi.org/10.1111/hic3.12436.

21 'The Fred Johns Scholarship for Biography', Faculty of Arts, University of Adelaide, accessed 27 May 2018, arts.adelaide.edu.au/scholarships/fred_johns_scholarship.html.

22 'The Seymour Biography Lecture', National Library of Australia, accessed 10 May 2018, www.nla.gov.au/ events/seymour-biography-lecture.

23 Brenda Niall, Life Class: The Education of a Biographer (Melbourne: Melbourne University Press, 2007). 
(Raymond Monk, 2014), political biography (David Day, 2009), biography and fiction (Robert Drewe, 2015, and Drusilla Modjeska, 2013), and family memoir (Raymond Gaita, 2017).

Publishers have also come to form part of the biographical infrastructure. Melbourne University Press, as Mark McKenna noted, has been particularly active publishing retired politicians' autobiographies, while in South Australia, the Wakefield Press has also been active in the genre. ${ }^{24}$ Biographical works have regularly featured in the major Australian literary awards for non-fiction. McKenna's biography, An Eye for Eternity: The Life of Manning Clark, has been the most successful, taking out many of the major awards: the non-fiction category of the Prime Minister's Literary Award (2012), the Nettie Palmer Prize for Non-Fiction (2011), the Victorian Premier's award for non-fiction (2011), the Douglas Stewart prize (2012), the Queensland Premier's award for non-fiction (2011) and the Adelaide Festival award for nonfiction (2012). In 1996 Dr Geoffrey Cains, later joined by the late Michael Crouch AC, established the annual National Biography Award. ${ }^{25}$ Recognising the best published work of biographical or autobiographical writing by an Australian, it seeks thereby to encourage 'the highest standards of writing biography and autobiography', and to promote public interest in biography. ${ }^{26}$ The shortlists over its lifetime attest to the volume, and the variety, of Australian biographical writing. Not only has it featured historical and literary biographies of the famous and the infamous, but also captured autobiography and memoir. It has thus put the spotlight on such works as Barry Hill's biography of Theodore Strehlow, Broken Song (2002) and Phil Butterss's life of C. J. Dennis, An Unsentimental Bloke (2014), while also featuring transnational Australian lives, such as Gabrielle Carey's family memoir of Randolph Stow, Moving Among Strangers (2013) and Peter Fitzpatrick's The Two Frank Thrings (2012), and sojourners such as Alison Alexander's The Ambitions of Jane Franklin (2013) and Alasdair McGregor's double biography of Walter Burley and Marion Mahoney Griffin, Grand Obsessions (2009).

\footnotetext{
24 Mark McKenna, “The Character Business”: Biographical Political Writing in Australia', in A Historian for All Seasons: Essays for Geoffrey Bolton, ed. Stuart Macintyre, Lenore Layman and Jenny Gregory (Melbourne: Monash University Publishing, 2017), 48-70.

25 The Rudd Labor Government established the Australian Prime Minister's Literary Awards in 2008 and biographies have won the non-fiction award: Evelyn Juers's House of Exile: The Life and Times of Heinrich Mann and Nelly-Kroger Mann won in 2009; Mark McKenna's An Eye for Eternity: The Life of Manning Clark won in 2012; Gabrielle Carey's Moving among Strangers and Helen Trinca's Madeleine: A Life of Madeleine St John were joint winners in 2014; Darleen Bungey's John Olsen: An Artist's Life and Michael Wilding's Wild Bleak Bohemia: Marcus Clarke, Adam Lindsay Gordon and Henry Kendall were joint winners in 2015; and Sheila Fitzpatrick's On Stalin's Team and Karen Lamb's Thea Astley: Inventing Her Own Weather were joint winners in 2016.

26 The State Library of NSW administers it, see 'About the Award', accessed 10 May 2018, www.sl.nsw.gov.au/ about-library-awards-national-biography-award/about-award.
} 
In universities, perhaps the most significant development in biographical infrastructure has been the inception in 2008 of the National Centre of Biography at ANU, and the decision to locate it in the Research School of Social Science's School of History. There had been short-lived predecessors, such as the Institute for Modern Biography at Griffith University (established in 1976) and the Institute of Biography, also at ANU, but the National Centre of Biography initiative has been sustained. ${ }^{27}$ Its establishment was partly a matter of financial necessity. The Australian Dictionary of Biography $(A D B)$ had been running since 1957 and, although it had organised the occasional conference and seminar, its sole function had always been the production of national biography. Yet by 2007 there was a widespread sense that its location within the university should be reconsidered-after all, among the 'family' of national biographical compendiums, it was conspicuous in being sponsored and supported by a university. ${ }^{28}$ The resultant 'Gregory Review', though, recommended that ANU should retain the $A D B$, finding in it a 'data infrastructure' that would enhance the university's potential to undertake 'cutting edge thematic research'. It suggested that the $A D B$ 's days as a single purpose entity were numbered, and advocated ways of increasing its potential as a scholarly resource. In particular, it should become a vehicle for the study of biography, reformed and integrated into the discipline of history and be subject to comparable educational and research expectations as other university departments. Along with the production of the $A D B$, the centre should promote and host biographical research and publication, and become the leading venue for biographical research by accommodating research fellowships, postgraduate research and graduate programs.

The National Centre of Biography, although conspicuous in Australia, is not alone in an international context, although it is unique in its responsibility for a national biographical dictionary. There is indeed a certain kinship in the study of biography, with many research and teaching centres, including the National Centre of Biography, being members of 'The Biography Society', which is currently located at Aix Marseille University, France. ${ }^{29}$ In 1988 the Centre of Biographical Research was established at the University of Hawai $i$; it was formed around the international journal Biography: An Interdisciplinary Quarterly, which had been

\footnotetext{
27 The Institute for Modern Biography, School of Humanities, Griffith University, under the direction of James Walter, had visiting fellowships and a seminar. A Biography Institute at ANU, which Paul Pickering directed, mostly served the Seymour Lecture. See James Walter, ed., Reading Life Histories: Griffith Papers on Biography (Brisbane: Institute for Modern Biography, Griffith University, 1981); James Walter and Raija Nugent, eds, Biographers at Work (Nathan Queensland: Institute for Modern Biography, 1984).

28 The only other national dictionary project situated within academia is the Dictionary of Canadian Biography.

29 The Biography Society is a scholarly society of research, international and interdisciplinary, devoted to the development and the valorisation of the theory and the practice of biography. Its members are Aix-Marseille University, Biography Institute, Biographers International Organization, Center for Biographical ResearchHawai'i, Center for Microhistorical Research, Centre for Life-Writing Research-King's College, European Network on Theory and Practice of Biography, National Centre of Biography-Australia, International Auto/ Biography Association, Oxford Centre for Life-Writing and Société des Anglicistes de l'Enseignement Supérieur (SAES). See biographysociety.org/about/ (accessed 21 May 2018).
} 
established in $1978 .{ }^{30}$ A professor of history and biography theory at the University of Groningen, the Netherlands, Hans Renders has been head of its Biography Institute since 2004. He is tasked with developing '... theoretical framework with regard to biography as an academic genre'. ${ }^{31}$ A number of biography centres were established to promote scholarly collaboration in biography. At the City University of New York, the Leon Levy Center for Biography was established in 2007. In England, the Centre for Life History and Life Writing Research was established at the University of Sussex in 1999. At Kings College London, the Centre for Life Writing Research was formed in 2007, and in 2010 at Wolfson College, the Oxford Centre for LifeWriting was founded, initially under Hermione Lee, and now Elleke Boehmer. Kathryn Hughes is director of life writing at the University of East Anglia. In 1996 Jane Ridley founded an MA in biography at the University of Buckingham and, in 2001, East Anglia began offering an MA in biography and creative non-fiction. For its part, between 2012 and 2017, the National Centre of Biography offered a masters of biographical research and writing, a graduate program that had evolved from the 'Using Lives' postgraduate workshops co-hosted by ANU and the National Museum of Australia and convened by Nicholas Brown. The centre continues to teach a graduate level course in biography and history.

As well as promoting academic research and scholarly fellowship, publication remains fundamental to the National Centre of Biography's role. While the $A D B$, which publishes online each year over 100 research-edited biographies of between 650 and 5,000 words, is its principal raison d'être, the centre puts out an array of other publications, including a newsletter, Biography Footnotes, and its regular column in the ANU Reporter, Life Sentences. It convenes an editorial board for the ANU Press series ANU.Lives, which, since 2014, has put out over a dozen monographs and edited collections, and in 2014 published online Using Lives: Essays in Australian Biography and History. The Australian Journal of Biography and History is a logical next step and is consistent with the recommendations of the Gregory Report that a National Centre of Biography should be 'more outward looking', and become a 'focus for the study of biography in Australia, maintaining that study in line with the highest and most innovative biographical work internationally. ${ }^{32}$ Existing journals will certainly influence the new journal, but it will aim to carve

\footnotetext{
30 Craig Howes has been the director of the Center for Biographical Research since 1997, and the editor and coeditor of Biography: An Interdisciplinary Quarterly since 1994. As CBR director, he is also general editor of the Biography Monograph Series, co-published with the University of Hawai'i Press. Since 2000, he has served as series scholar and co-producer for the Biography Hawai' $i$ television documentary series.

31 It was relocated within the Department of History and Theory of Biography in 2012. It has two objectives, 'to offer both a supportive infrastructure and more specific support related to a variety of subjects for graduate students engaged in biographical research' and 'to stimulate the further development of a theoretical framework with regard to the biography as an academic genre'. 'About the Biography Institute', University of Groningen, accessed 3 July 2018, www.rug.nl/research/biografie-instituut/?lang=en.

32 Australian Dictionary of Biography, Working Party Report to the Director (the Gregory Report), Research School of Social Sciences Review, 2007.
} 
out its own domain in the sphere of biography and life writing. For example, Biography emphasises biography as a craft and a literary art, and seeks to be both interdisciplinary and United States-focused. Its articles aim to stimulate debate on the theoretical, generic, historical and cultural dimensions of life writing, and the integration of literature, history, the arts and the social sciences as they relate to biography. The journal Life Writing publishes articles on biography and autobiography, including scholarly articles and critically informed personal narratives, and again pursues the interdisciplinary, while welcoming contributions from specific disciplines. The Journal of Historical Biography, founded in 2007, set out to publish biographical portraits of prominent individuals, reviews, and theoretical, methodological and philosophical articles on the practice of biography and autobiography. Located at the University of the Fraser Valley, British Columbia, and funded by the Canadian Social Sciences and Humanities Research Council, it suspended publication in 2014. The formation of the National Centre of Biography at ANU, then, is a part of a wider institutional wave.

\section{Australian biography and the legacy of existing structures}

While part of wider international developments, the $A D B$ was above all a product of Australian historical practice itself. During the 1950s historians accepted that there were sufficient Australian sources and historiography to sustain full biographies. ${ }^{33}$ In 1957 Keith Hancock called a national conference at ANU, during which participants agreed that the priority on developing archival collections had scotched earlier concerns that sources were too meagre to sustain detailed biographical research. Three recent studies illustrate the point. Alison Alexander's portrait of Jane Franklin is impressively light on its feet, given that she drew on a huge body of hitherto unpublished research as well as Franklin's extraordinarily voluminous journals, more than 8 million words in total, to write full and astute biography. ${ }^{34}$ Similarly, Mark McKenna utilised an immense archive to write his biography of Manning Clark. ${ }^{35}$ Clark 'lived to be remembered'; there are 198 boxes of his papers in the National Library of Australia with various directions to future biographers within them. ${ }^{36}$ Part of McKenna's task was an 'extended mediation on the Clark archive', always critically assessing it and 'wrest[ing] control of the

33 Nolan, 'Country and Kin Calling?', 247-72.

34 Alison Alexander, The Ambitions of Jane Franklin: Victorian Lady Adventurer (Crows Nest, NSW: Allen and Unwin, 2013).

35 Mark McKenna, An Eye for Eternity: The Life of Manning Clark (Carlton, Vic: Miegunyah Press, 2011).

36 Papers of Manning Clark, 1907-1992, MS 7550, National Library of Australia. 
life from [Clark's] extremely controlling voice'. ${ }^{37}$ Jim Davidson's biography of the historian W. K. Hancock drew on 45 archival repositories and private collections in Australia, South Africa, England, Ireland and the United States of America. ${ }^{38}$ In her recent biography of the Australian author Randolph Stow, Suzanne Falkiner also worked with a vast body of personal memoirs, and letters, journals and papers held by the National Library of Australia, to document the story of one whose life and consciousness spanned Europe and Australia. ${ }^{39}$ Such works show that Australian biographies cannot always be contained by the continent and its adjacent islands. Australian biography is written by Australians or about Australians, often involving subjects who were expatriate, had extensive sojourns elsewhere or were born outside the country. Some never even came to the land, but it lived in their imaginations, as with the $A D B$ biographies of the Portuguese adventurer Pedro Ferdinand de Quiros (1563-1615) and the English writer Charles Dickens (1812-70).

Among the corpus of Australian historical biography are conservative as well as path-breaking works. Best sellers are not necessarily the best books, but everyone will have a personal favourite. Historians have recently published many standard biographies of significant Australians: Ann Blainey on Melba, and Alasdair McGregor on Walter Burley Griffin and Marion Mahony Griffin. The shortlist for the Prime Minister's award for Australian history in 2017 alone included two biographical works-John Murphy's life of H. V. Evatt and Neil McDonald's of the war correspondent Chester Wilmot ${ }^{40}$ - and two that utilised biography to relate significant events in Australian history: Charlie Ward's A Handful of Sand and Josephine Bastian's 'A Passion for Exploring New Countries': Matthew Flinders \& George Bass. ${ }^{41}$ In the non-fiction category, Tom Griffiths's The Art of Time Travel deployed biography to illuminate the significance of historians to contemporary Australian life. ${ }^{42}$ Some biographical works will undoubtedly become classics; Barry Hill's Broken Song: T.G.H. Strehlow and Aboriginal Possession is notable not only for its detailed biography of the subject, but also for its interest in penetrating the deep psychology of the subject. ${ }^{43}$ Raymond Gaita's 1998 biography of his father, Romulus My Father —which was made into a movie in 2007-grew out of the tribute he gave at his father's funeral, and developed less perhaps as a biographical account of a life

37 Mark McKenna, “A Gigantic Confession of Life”: Autobiography, "National Awakening” and the Invention of Manning Clark', in Clio's Lives: Biographies and Autobiographies of Historians, ed. Doug Munro and John G. Reid (Canberra: ANU Press, 2017), 85.

38 Jim Davidson, A Three-Cornered Life: The Historian W. K. Hancock (Sydney: UNSW Press, 2010).

39 Suzanne Falkiner, Mick: A Life of Randolph Stow (Nedlands, WA: UWA Publishing, 2017).

40 John Murphy, Evatt: A Life (Sydney: NewSouth, 2016); Neil McDonald with Peter Brune, Valiant for Truth: The Life of Chester Wilmot, War Correspondent (Sydney: NewSouth Publishing, 2016).

41 Charlie Ward, A Handful of Sand: The Gurindji Struggle after the Walk-Off (Melbourne: Monash University Publishing, 2016); Josephine Bastian, 'A Passion for Exploring New Countries': Matthew Flinder \& George Bass (Sydney: Australian Scholarly Publishing, 2016).

42 Tom Griffiths, The Art of Time Travel: Historians and Their Craft (Sydney: Black Inc., 2016).

43 Barry Hill, Broken Song: T.G.H. Strehlow and Aboriginal Possession (Milsons Point, NSW: Vintage, 2002). 
than as a personal memoir to try to understand a complex and conflicted man. ${ }^{44}$ Rose Boys, by Peter Rose, and My Father's Daughter, by Sheila Fitzpatrick, similarly illustrate the sometimes porous boundaries between biography, autobiography and memoir, and family history. ${ }^{45}$ Alexis Wright's Tracker: Stories of Tracker Tilmouth is based on a wealth of oral interviews, the author portraying it more as a 'collective memoir' than a biography. ${ }^{46}$

Such lists, though, overlook the lingering bias in the corpus of Australian biographical work. While there are many more biographies appearing on Australian women and Indigenous subjects, structural challenges linger. In 2011 a panel on International Women's Day at Melbourne's Readings bookshop discussed the under-representation of women on the literary pages of the major Australian newspapers, both as reviewers and as authors of the books reviewed. That same year, 70 per cent of the books reviewed in the Weekend Australian's books pages were written by men. The panel also discussed the absence of women as winners of literary prizes. Only 10 individual women had ever won the Miles Franklin Literary Award over its 54-year history. Women, though, are increasingly winning prizes for biography as Richard Evans, a long-time judge of the British Wolfson Prize, noted:

Nine out of the 21 winners in the last 10 years have been women, whereas in the previous 10 years there were only four women out of a total of 24 ... It's striking that the female historians who have won the prize have written about a whole variety of subjects ... True, these are not all books that have topped the bestseller lists. But that's only a crude and rather misleading yardstick. If you take quality history with an appeal beyond the academic, then women are finding publishers and readers and winning prizes too. ${ }^{47}$

Nevertheless, most surveys indicate that biography is still mostly written by men about male subjects, a bias that strongly suggests that the most popular biographies continue to reflect the social, intellectual and political standing of a subject. ${ }^{48}$ Antony Beevor, the author of many best-selling war accounts, suggests obvious historical reasons for this continuing partiality:

\footnotetext{
44 Raimond Gaita, Romulus, My Father (Melbourne: Text Publishing, 1998).

45 Peter Rose, Rose Boys (Sydney: Allen \& Unwin, 2001); Sheila Fitzpatrick, My Father's Daughter: Memories of an Australian Childhood (Melbourne: Melbourne University Press, 2010).

46 Alexis Wright, Tracker: Stories of Tracker Tilmouth (Artarmon, NSW: Giramondo Publishing Company, 2017).

47 Richard J. Evans, “Big Books by Blokes about Battles”: Why Is History Still Written Mainly by Men?' Guardian, 6 February 2016, accessed 23 August 2018, www.theguardian.com/books/2016/feb/06/books-blokesbattles-history-written-by-men.

48 Evans, “'Big Books by Blokes about Battles”.
} 
A male preponderance in historical biography is thus fairly predictable for the obvious reason that, until very recently, women had little chance of distinguishing themselves because of ignorant prejudice. And since books on major historical figures sell better than those on the lesser known, there is almost inevitably a selfperpetuating element there. ${ }^{49}$

In the $A D B$ only 12 per cent of its 13,000 biographical subjects are women, an imbalance that is even more notable when the early volumes alone are considered; in the first four volumes, 48 (just over 4 per cent) of the 2,212 subjects were women. Similarly, Aboriginal and Torres Strait Islander subjects have fared badly, and currently comprise only 1.6 per cent of 13,000 published $A D B$ entries, and in some earlier volumes not a single Aboriginal person was considered sufficiently notable to warrant an entry. A conscious effort is needed to remove this bias, which not only entails an effort to notice and include, but a redefinition of what entails 'significance'. Thus in 2005 a supplementary volume of the $A D B$, funded by the Australian Research Council (ARC), had 30 per cent women and 9 per cent Indigenous subjects, a strategy that had a notable, though incremental, impact on the total corpus. The Dictionary of New Zealand Biography (DNZB), published from 1990 to 2000, adopted a more vigorous strategy to include Māori, which included establishing an advisory group, recruiting language experts and involving Māori as authors. As a consequence, the $D N Z B$ has two volumes of Māori and Pasifika New Zealander subjects, which are presented bilingually. Similarly, two recent projects of the $A D B$ aim to increase the numbers and proportions of women and Indigenous people. Its colonial women project was launched in 2016 and, after a nationwide call for nominations, has developed a list of 1,500 women from the colonial era who warrant inclusion. The ARC-funded 'Indigenous Australian Dictionary of Biography' project, a joint venture between the $A D B$ and the University of Western Australia, will add 190 new biographies to the online corpus, and will result in a stand-alone publication of new biographies and the existing 210 $A D B$ entries on Indigenous subjects, some of them rewritten or substantially revised. As with New Zealand, the project represents a collaboration with Indigenous Australia and, as a consequence, substantial changes to the structure of the $A D B$ have come about, both to its editorial board and, with the formation of an Indigenous Working Party made up solely of Aboriginal and Torres Strait Islander scholars from each state and territory, its working parties. Preparedness to enter a partnership with Indigenous Australia, though, also places an obligation on organisations such as the $A D B$ to re-examine a modus operandi entrenched by 60 years of largely successful production. Not only does this mean a review of how subjects are chosen and a consideration of matters such as Indigenous intellectual property, but also a reconsideration of the parameters of 'national significance' to encompass Aboriginal meanings, and how the succinct style of the $A D B$ biography can be adapted cross-culturally.

49 Evans, “'Big Books by Blokes about Battles”. 


\section{A distinctive Australian school of biography?}

In a recent article, Daniel R. Meister argued that 'a Dutch school of biography' is seeking to combine biographical methods with the theoretical approaches of microhistory. ${ }^{50}$ Biography is moving away from the 'less scholarly life writing tradition', which has been accused of marshalling the facts of a life for purposes that are unclear and 'of searching for meaning in trivia'. In seeking a 'middle ground' between foregrounding the life and foregrounding the times, this approach to biographical writing recognises that individuals influence the institutional frameworks in which they live, and that their lives cannot be explained solely by the times in which they live and the institutional forces they are subject to. Failure to recognise individual agency will inevitably obscure the reality of peoples' 'complex, contradictory, messy lives' and the 'inexhaustible' disparity, as Sabina Loriga put it, between explaining institutions through individuals and, conversely, individuals through institutions. ${ }^{51}$ The two spheres cannot exist in a vacuum, for just as biographers and microhistorians might ask how historical narratives relate to a real life, biography and microhistory can validate or invalidate theories about broader topics.

Biographers have generally been uninterested in theorising. As Ian Hancock recalled when he was beginning his biography of John Gorton:

Despite decades of theoretical under-nourishment, and feeling quite healthy nonetheless, I sallied forth remembering the tale of Hilaire Belloc's water beetlebetter just to swim, for to stop and think, would be to sink. ${ }^{52}$

Yet there continues to be substantial discussion about the relationship between history and biography and, particularly in literary biography, the relationship between the biographer and the subject. If there is a theory of biography, it is perhaps what some have termed 'expressivist anthropology', the assumption that 'by their words and deeds shall you know them'. ${ }^{53}$ With the primary focus on the life itself, and the context of the life a secondary consideration, such a method, which has been called 'classical biography', is microhistory in its narrowest sense; as Meister remarks, it is like 'identifying subjects as dots and refus[ing] to connect them'. ${ }^{4}$ The biographical quest thus becomes one of selecting and capturing the 'authentic' expressions of a subject, assuming all humankind to be creatures of 'self-defining subjectivity'.

\footnotetext{
50 Meister, 'The Biographical Turn'.

51 Sabina Loriga, 'The Plurality of the Past: Historical Time and the Rediscovery of Biography', in Renders, de Haan and Harmsma, The Biographical Turn, 34.

52 Ian Hancock, 'Biography and the Rehabilitation of the Subject: The Case of John Gorton', in Australian Political Lives: Chronicling Political Careers and Administrative Histories, ed. Tracey Arklay, John Nethercote and John Wanna (Canberra: ANU E Press, 2006), 62.

53 Park Honan, 'The Theory of Biography', in NOVEL: A Forum on Fiction 13, no. 1 (Autumn 1979): 109-20.

54 Meister, 'The Biographical Turn', 5.
} 
Various theoretical approaches are open to a biographer in seeking to understand the subject, including ego-psychology and psychoanalysis, and from this perspective it is interiority, rather than sociability, that is of interest. Microhistory, though, also has the potential to recognise that humans function in a range of milieusocial, political, economic and family-that are in turn shaped and influenced by larger forces and processes. This is territory in which historical biography should be comfortable, as it allows considerable scope to apply theoretical perspectives, as well as diverse historical perspectives including the transnational, environmental, political and Indigenous, in order to understand the individual as a social and political being. Academic historians have a concern for context and a training that enables them to establish it more fully than academics in other disciplines. To Meister, historical biography should 'alternate its gaze' between subject and context, seeking to examine both a life and historical events and processes to examine how they are interwoven. ${ }^{55}$

So can we discern similar developments that might suggest an Australian 'school' of biography? We propose that a long-standing interest by Australian historians in autobiography and a growing interest in prosopography constitute two forms that have exercised a marked influence on Australian biography. Jeremy Popkin described how Australian historians adopted 'egohistoire' long before Pierre Nora challenged historians to consider 'the link between the history you have made and the history that has made you', ${ }^{56}$ and thus to consider the links between biography and autobiography. Without what Popkin called the 'theoretical pretensions' of French egohistoire, Australian historians more than any other national group have used their autobiographical accounts to question major rungs of the Australian national story, and their works have come to be regarded as 'major contributions to the national literature' ${ }^{57}$ As doubts arose about the ability of historical accounts to be objective, and faith in the grand narratives of liberalism, Marxism and nationalism declined, historians were increasingly drawn to approaches 'that emphasised ordinary experience: microhistory, the history of everyday life, women's history' ${ }^{58}$ The autobiographical writing of historians such as Keith Hancock, Jill Ker Conway, Kathleen Fitzpatrick, Manning Clark and Bernard Smith has long been valued in the Australian literary canon, as personal and family memoir certainly, but also for its capacity to 'confront questions about the relationship between personal and national pasts that are quite different from those encountered by their colleagues in other countries'. ${ }^{59}$ Of course it is the very diversity of autobiography that makes it

55 Meister, 'The Biographical Turn', 5.

56 Jeremy D. Popkin, History, Historians, \& Autobiography (Chicago \& London: University of Chicago Press, 2005), 74, 90; Jeremy D. Popkin, 'Ego-Histoire Down Under: Australian Historian Autobiographers', Australian Historical Studies 38, no. 129 (2007): 106-23.

57 Popkin, History, Historians, \& Autobiography, 90.

58 Popkin, 'Ego-Histoire Down Under', 109.

59 Popkin, 'Ego-Histoire Down Under', 107. 
such an attractive literary and historical form, and such accounts vary considerably in their approaches, perspectives and interests. For instance, Hancock, Smith and Clark appeared little concerned with the position of women in Australian society, and were more concerned with what they took to be the big questions of Australian identity, and intellectual and cultural life. In 1998 Conway argued that 'memory's plots - the language and narrative forms of autobiography-were developed to interpret male lives. In the past, women writing autobiography experienced a degree of difficulty because the genre denigrated female experience and celebrated the 'experience of the atomistic Western male hero'. She surveyed this cultural tradition from its eighteenth-century beginning with a careful analysis of autobiographies by Jean-Jacques Rousseau and Benjamin Franklin. The breakdown of the symbolic male hero was accompanied by changing cultural assumptions. Conway argued that patterns of autobiographical writing lay 'not in theory but in cultural history', with its forms and stylistic kinds varying. ${ }^{60}$ Subsequently, Ann Moyal has pointed out that Australian women historians have taken up the autobiographical challenge in recent decades with gusto, establishing a "complementary culture" to male autobiography with its ongoing emphasis on national identity and image'. ${ }^{61}$

Indigenous Australia was also of little interest, at least in the earlier autobiographical works of historians, although Clark and Smith later came to recognise that this was a serious absence. For Henry Reynolds, autobiography provided a vehicle for tackling an issue that he believed went to the core not only of his Australian identity, but also of his identity as an Australian historian. In his 1999 memoir Why Weren't We Told? he confronted the complicity of his discipline in concealing the violence and dispossession of the frontier, and in promoting what W. E. H. Stanner called the 'great Australian silence'. ${ }^{62}$ Other Australian writers, although not strictly members of the discipline, also used an emerging consciousness about Aboriginal history in their memoirs and autobiographical works. For example, John Mulvaney, often called the 'father' of Australian archaeology, described the emergence of Aboriginal involvement in his discipline and the growth of his own awareness of Aboriginal history in his autobiography Digging Up a Past (2011). ${ }^{63}$ Earlier, the poet and author Judith Wright wrote two memoirs of her family's New England pastoral holding, Generations of Men (1959) and A Cry for the Dead (1981), in which she explored her own moral anguish over her love of the land and the guilt

60 Jill Ker Conway, When Memory Speaks: Reflections on Autobiography (New York: Alfred Knopf, 1998), 3-4. Previously Conway had edited Written by Herself: Autobiographies of American Women: An Anthology (New York: Vintage Books, 1992) and Written by Herself, vol. 2, Women's Memoirs from Britain, Africa, Asia, and the United States (London: Vintage, 1996).

61 Ann Moyal, 'The Female Gaze: Australian Women Historian's Autobiographies', in Clio's Lives: Biographies and Autobiographies of Historians, ed. Doug Munro and John G. Reid (Canberra: ANU Press, 2017), 65.

62 Henry Reynolds, Why Weren't We Told? A Personal Search for the Truth about Our History, (Ringwood, Vic.: Viking, 1999).

63 D. J. Mulvaney, Digging Up a Past (Sydney: UNSW Press, 2011). 
of her family's invasion and dispossession of the Aboriginal traditional owners. ${ }^{64}$ As a parallel phenomenon, Aboriginal writers were increasingly attracted to auto/ biography and memoir to relate their own stories of colonisation and survival, and through this the history both of their own language groups and Aboriginal Australia. Sally Morgan's My Place (1987), although not the earliest Aboriginal autobiography, was the first to achieve mass sales in Australia and internationally. For the first time, many European Australians learned about the impact of past government policies on Aboriginal communities and families, and, perhaps more importantly, became aware of the strategies Aboriginal people had been forced to adopt in order to survive. In 1999 Conway noted that Morgan's narrative was 'in the first person', which was to be expected of an 'oral culture'; Morgan's resort to autobiography followed from the nature of her sources. ${ }^{65}$ The 'Australian Indigenous Autobiography Archive' on the National Centre of Biography website lists only 50 such works, but it shows the depth and geographic range of a vibrant form of Aboriginal self-writing, holding details of works by significant Aboriginal Australians such as Cathy Freeman, Jack Davis, Charles Perkins, Anthony Mundine and Nova Peris. ${ }^{66}$ Many document the stories of parents and grandparents, as well as the storyteller's childhood, and they often deal with the trauma of family separations, children's institutions and gaol, as well as the way people made a living and sometimes, despite the odds, thrived.

Family history, long the province of genealogy and amateur historians, has recently become an additional tool for Australian historians to illuminate aspects of Australian history. Graeme Davison, for example, began to write an account for his family - a common motivation for family historians-but decided it had much to reveal about Australian foundations more generally and so made it public. ${ }^{67}$ Likewise Nick Brodie had long been interested in his family history, boasting forebears who were present at some of the formative events of Australian history - the first fleet, bushranging, Eureka Stockade and both world warsand their experiences gave a new and often unique perspective. ${ }^{68}$ Penny Russell is tracing her forebears, the Thompsons, a 'steerage class' family whose perceptions of class, commerce and religion in colonial Sydney acts as a powerful counterpoint to establishment accounts. ${ }^{69}$ Similarly, Ann Curthoys identified members of her family in the 'Legacies of British Slave Ownership' database project. Led by the British

64 Judith Wright, Generations of Men (Melbourne: Oxford University Press, 1959); Judith Wright, A Cry for the Dead (Melbourne: Oxford University Press, 1981).

65 Jill Ker Conway, ed., In Her Own Words: Women's Memoirs from Australia, New Zealand, Canada, and the United States (New York: Vintage Books, 1999), 89-90.

66 Australian Indigenous Autobiography Archive search, National Centre of Biography website, ia.anu.edu. au?biographies/added/.

67 Graeme Davison, Lost Relations: Fortunes of My Family in Australia's Golden Age (Crows Nest, NSW: Allen \& Unwin, 2015).

68 Nick Brodie, Kin: A Real People's History of Our Nation (Richmond, Vic.: Hardie Grant Books, 2015).

69 Penny Russell, 'Travelling Steerage: Class, Commerce, Religion and Family in Colonial Sydney', Journal of Australian Studies 38, no. 4 (2014): 383-95. 
historian Catherine Hall at University College London, the project aimed to identify a hitherto hidden aspect of emancipation: the way that compensation payments by the British Government for those compelled to release slaves provided capital for ventures in the Australian colonies. ${ }^{70}$ The presence of Curthoys's ancestors on the database provided a new perspective on their subsequent migration to Australia and efforts to establish themselves in a new land, one that may well have been shared by numbers of their fellow colonisers.

Even with the vastly improved access to historical and biographical sources the digital world has provided, deficiencies in the sources remain at particular points and in particular areas. It is partly to overcome such deficiencies, Curthoys recently suggested, that the perspectives of contemporary authors become so pertinent, as they provide an avenue to compensate for documentary silences and absences. A family historian can to some extent fill these gaps, not only by asking questions of the sources but also by marshalling such relative intangibles as family stories and myth, tradition and imagery. From a vantage point that is at once detached and intrinsically personal, and adopts a historical perspective that concurrently looks back and forward, egohistoire inserts the storyteller into the family narrative, and has rapidly become an effective method of Australian history-making.

In 1998 Macintyre observed that prosopography, or collective biography, had not been widely practised in Australia, but works such as Mollie Gillen's The Founders of Australia (1989), Janet McCalman and Mark Pell's Who Went Where in Who's Who 1988 (1992), and McCalman's Journeyings: The Biography of a Middle-Class Generation 1920-1990 (1993) suggested enormous methodological possibilities. ${ }^{71}$ The second way in which Australian biography might be considered distinctive, then, is prosopography. Australian historians have shown particular interest in collective biography in the last two decades. As with the motivation towards autobiography, explanations for the potential of prosopography in Australian history lie partly in the nature of historical sources, in which the state dominated colonial and postcolonial settlement and, in the process, built up a massive body of longitudinal data, from convict transportation, assisted migration, soldiers, mental health records of repatriated soldiers, stolen children and welfare records. Such records have long been available to historians, and compendiums such as 'Historical Records of Australia' and the three-volume Dictionary of Western Australians, ${ }^{72}$ were invaluable to historians of past generations. Yet the analytical power offered by computer technology now provides a means of enhancing their value, no less

70 Ann Curthoys, 'From Montserrat to Settler-Colonial Australia: The Intersecting Histories of Caribbean SlaveOwning Families, Transported British Radicals, and Indigenous Peoples', A. W. Martin Lecture, ANU, 22 May 2018. 71 Macintyre, 'Biography', 72.

72 Dictionary of Western Australians 1829-1914, 3 vols (Nedlands: University of Western Australia Press, 1979). 
labour-intensive in their initial phases than card and catalogue systems, but with a vastly increased capacity to organise, aggregate and manipulate the data to respond to historical questions.

McCalman went on to work with Hamish Maxwell-Stewart and others on the 'Founders and Survivors' project, a massive longitudinal study of 73,000 Tasmanian convict transportation records that built on Lloyd Robson's two-volume History of Tasmania $(1983,1990)$. The historical questions might have resembled those of past researchers, but the capacity to utilise 'big' data marked a turning point in Australian historiography. Mark Finanne's 'The Prosecution Project', which is documenting colonial criminal prosecutions in seven Australian jurisdictions over 150 years, is resulting in another exciting big database. ${ }^{73}$ In a similar vein, the National Centre of Biography is conducting a project to digitally analyse the 4,500 people who arrived in Australia on the first three fleets. Again it is asking classic historical questionswhere these people went, how they remade their lives in Australia, who their children and grandchildren were, and how these later generations fared. This project will eventually add about 110,000 individual records to the NCB websites. Such aggregate data allows prosopographical study in its truest sense, imparting a capacity to look at broad movements of people and generations, connections and networks, and to utilise digital tools, including the geospatial, to present and visualise the data. Yet importantly in the project of collective biography, it also seeks to incorporate depth by seeking means of tracking individuals and collectives across time and place. Big data can only do so much; there is no escaping the classic historical ventures of seeking out the material, recognising its relevance, trawling the newspapers in a quest made much easier by the search and find capacities of Trove, and then using often specially designed programs to extract their value.

With the onset of the digital realm, national dictionaries of biography have also had to make choices, and have not always immediately recognised the potential of digitisation to transform the value of their collections. The late Geoffrey Bolton, for example, wrote of the former general editor of the $A D B$, John Ritchie: 'His entrenched preference for the handwritten, although vindicated by his unfailingly neat calligraphy, left him slow to grasp the potential of online publication..$^{74}$ Most national dictionaries have been online for some time, but the prevailing focus remains the individual and digitisation simply a new paper-free means of publication, albeit with vastly improved search and browse functions. This characterised the $A D B$ 's initial response: costly, time-consuming but nevertheless essential machine-reading of the hardcopy volumes, the production of a $\mathrm{CD}$ and

73 The Prosecution Project, accessed 25 August 2018, prosecutionproject.griffith.edu.au/tag/mark-finnane/. See also Mark Finnane, 'The Prosecution Project: Investigating the Criminal Trial in Australian History', Humanities Australia 7 (2016): 35-45.

74 Geoffrey Bolton, 'John Ritchie: Consolidating a Tradition, 1987-2002,' in The ADB's Story, eds Melanie Nolan and Christine Fernon (Canberra: ANU E Press, 2013), 162. 
subsequent upload to the web. The rise of the digital humanities, however, illustrated the potential to vastly enhance the value of collections such as the $A D B$ through comprehensive indexing. This means that each of the 27,500 biographical entries on the three NCB websites - the $A D B$, Obituaries Australia and People Australia—are now linked and the information used to identify collectives and networks such as families, school and university communities, places of birth, military, business and professional associations. Such transformations are expensive, and the costs continue; the full potential of the digital world has meant firstly defining and then investing in a digital strategy. Two $A D B$ positions have had to be allocated to the digital strategy, one solely devoted to programming, maintaining the system and developing tools such as family trees, geospatial material, graphs and charts to manipulate and display the data. The $A D B$ has been entirely transformed, while losing nothing of its timehonoured reputation for the scholarly quality of its stand-alone biographies. Indeed this remains the primary interest of many of the 70 million users who visit the website each year. However, an increasing number are recognising the expansive nature of the $A D B$, particularly its potential for research. Compared with other big datasets, the $A D B$ might be small-fry, but its particular value again lies in the depth of its material, and thus its potential to explore collectives as multidimensional and complex.

To conclude, there are good reasons for believing that the principles of autobiography and prosopography give Australian biography a distinctive flavour. They have arisen, as we have suggested, in response to particular historical characteristics, including the postcolonial impetus in the country since World War II, and the nature of the archive and its extraordinary value in a digital environment. We anticipate that future numbers of the Australian Journal of Biography and History will dwell further upon such matters, including the interrelationships of biography and theory. In this first issue, a diverse range of essays primarily relates to questions of individuals and the contexts in which they functioned, exploring as Daniel Meister puts it, the 'middle ground' between a life and the times. Four of them concern Australian women who operated and negotiated various fields of endeavour, only one of which - the role of headmistress of a girls' school-was unambiguously a women's domain. The profile of Miss Annie Hughston (1859-1943) by Mary Lush, Elisabeth Christensen, Prudence Gill and Elizabeth Roberts, all of them former students at Fintona during Hughston's long tenure, shows how a strong figure could, perhaps, have a disproportionate influence on women entering male bastions. Similarly, Nancy Atkinson, a pioneering bacteriologist at the University of Adelaide, was not only a scientific researcher of note but also a teacher of generations of graduate students. Yet when the chair in her field finally became available, she was overlooked in favour of a male English import, despite having acted in the role for many years. She was valued it seems more for her teaching than her research, a classic tendency to ascribe to women in scientific circles a nurturing, rather than a knowledge-creating function. Jean Andruana Jimmy (1912-91), a Yupngayth woman from Mapoon in north 
Queensland, became prominent in community leadership and land rights activism, areas that had been assumed to be male spheres. Yet leading her community was by no means as revolutionary as was often assumed by outside European observers, for Andruana saw herself resuming a role that was entirely consistent with women's responsibilities, as Geoff Wharton describes. Sophie Scott-Brown, in her portrait of the playwright and director Eunice Hangar's interpretations of the works of William Shakespeare, examines the nature of reading as 'a simultaneously social and individualistic activity' and its implications for understanding the way Australians have read English writers.

The article by Brendan Dalton on his distant ancestor Fredrick Dalton, a journalist and later a gold commissioner on the New South Wales goldfields, explores the potential of nineteenth-century mobilities in the formation of identity. In Dalton's case, he twice remade himself, the first time by escaping seemingly difficult circumstances in the United States to begin a new career with a new identity in Australia, and later by engineering his disappearance from his Australian family to resume his previous life. Karen Fox explores how family history can illuminate an understanding of legal and power relations in a geographic setting, in this case Sydney. The Stephens and the Streets, who between them produced four chief justices of New South Wales, at least four judges, and a number of barristers and solicitors, formed what can be called a legal 'dynasty' that exercised significant influence in the legal arena, as thus in politics and political administration. The article on André Kostermans, a renowned Dutch Indonesian botanist, by Michèle Horne, is on one level a story of shifting identity. Her subject was born in the Dutch East Indies and, after training in botany in Holland, returned to take up his profession in the land of his birth. Interned by the Japanese during World War II, he used his skills to supplement the diet of his fellow prisoners of war, many of them Australian, as well as to develop a 'bush' procedure for producing surgical-grade alcohol, actions that undoubtedly saved the lives of many. After the war, and having taken out Indonesian citizenship, his career was almost ruined by the government's response to his homosexuality. In the final essay, the University of Xian scholar Tiping Su, who spent a year as a visiting scholar at ANU in 2015-16, discusses the problem of the 'missing' Chinese in the $A D B$, explaining the various issues in identifying and historicising the many Chinese who sojourned in Australia, as well as those who stayed. In concluding he identifies a number of significant Chinese people who might warrant inclusion in the $A D B$, and proposes ways by which Australian and Chinese scholars might together approach the task both at a collective and an individual level 
This text is taken from Australian Journal of Biography and History: No. 1, 2018, published 2018 by ANU Press, The Australian National University, Canberra, Australia.

doi.org/10.22459/AJBH.2018.01 